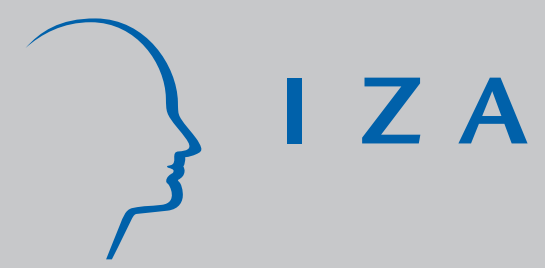

IZA DP No. 6934

Are We There Yet?

Time for Checks and Balances on New Institutionalism

Murat Iyigun

October 2012

Forschungsinstitut zur Zukunft der Arbeit Institute for the Study of Labor 


\title{
Are We There Yet? Time for Checks and Balances on New Institutionalism
}

\author{
Murat Iyigun \\ University of Colorado \\ and IZA
}

\section{Discussion Paper No. 6934 \\ October 2012}

\author{
IZA \\ P.O. Box 7240 \\ 53072 Bonn \\ Germany \\ Phone: +49-228-3894-0 \\ Fax: +49-228-3894-180 \\ E-mail: iza@iza.org
}

Any opinions expressed here are those of the author(s) and not those of IZA. Research published in this series may include views on policy, but the institute itself takes no institutional policy positions. The IZA research network is committed to the IZA Guiding Principles of Research Integrity.

The Institute for the Study of Labor (IZA) in Bonn is a local and virtual international research center and a place of communication between science, politics and business. IZA is an independent nonprofit organization supported by Deutsche Post Foundation. The center is associated with the University of Bonn and offers a stimulating research environment through its international network, workshops and conferences, data service, project support, research visits and doctoral program. IZA engages in (i) original and internationally competitive research in all fields of labor economics, (ii) development of policy concepts, and (iii) dissemination of research results and concepts to the interested public.

IZA Discussion Papers often represent preliminary work and are circulated to encourage discussion. Citation of such a paper should account for its provisional character. A revised version may be available directly from the author. 
IZA Discussion Paper No. 6934

October 2012

\section{ABSTRACT \\ Are We There Yet?
Time for Checks and Balances on New Institutionalism ${ }^{1}$}

New institutionalism has had considerable success during the last decade in shepherding the debate on sustained economic development. If the sociopolitical, legal and economic transformations in the Anglo-Saxon world in the last three decades prove anything, however, it is that the late Mancur Olson deserves some long overdue credit. For the relevant question now is why have some constitutional democracies deteriorated to the point of chronic dysfunction with their checks and balances failing. New institutionalists then ought to come to terms with the fact that, in the interest of credible empirical identification, they too narrowly defined what Northian institutions entail. As a matter of fact, political, legal and economic institutions are highly malleable even in advanced economies, while sustained economic growth could well be deep rooted in individual beliefs, social norms and informal cultural organizations.

JEL Classification: O11, O57, N10

Keywords: institutions, economic growth, development

Corresponding author:

Murat lyigun

Department of Economics

University of Colorado

Boulder, CO 80309-0256

USA

E-mail: murat.iyigun@colorado.edu

\footnotetext{
${ }^{1}$ Prepared for the Beloit College 2012 Upton Scholar Forum in honor of Timur Kuran. I am grateful to Lee Alston and Dani Rodrik for their invaluable input, corrections and suggestions, although neither bears responsibility for my thinking.
} 
In academic circles, the last decade has witnessed the widespread acceptance of institutions as the primal cause of sustained economic development. Douglass North's (1990) seminal ideas came home to roost empirical validation and triumphant fruition two decades years later through the findings of Acemoglu, Johnson and Robinson (2001), Rodrik, Subramanian and Trebbi (2004) and, to a lesser extent, others. ${ }^{2}$

The core of North's ideas revolves around formal institutions and the political as well as economic "rules of the game". But his functionalist take on what constitutes institutions that potentially impinge upon sustained economic growth and development is much broader. It not only acknowledges that social norms, beliefs and informal organizations matter for economic development, but also that formal political institutions could be malleable, with the softer and harder to measure institutional determinants coming to bear on the formal rules of the game.

For the empirical literature that came to dominate the institutionalist debate in the last decade, however, the path to identification and empirical credibility lay in narrowing the definition of institutions such that the latter could be observable and quantifiable. This is, in essence, why institutions in the development economics context have come to be synonymous with formal political and economic rules of the game.

These qualifications aside, it seemed that the $\$ 64,000$ question was finally laid to rest. With the Herculean task of identification ingeniously-albeit somewhat questionably ${ }^{3}$ - tackled, reversals of fortune were now explained; the causal effects of geography, culture, trade, colonialism, imperialism, and slavery were ruled out; the Western-centric prescriptive foundations of policy guidance to the Third World were set. $^{4}$

Accordingly, the narrative went, Latin American, Middle Eastern, African and Iron-curtain countries were poor because their economic and political elites

\footnotetext{
2 An incomplete list of complementary empirical papers includes Hall and Jones (1999), Easterly and Levine (2003), and admittedly my own in Iyigun and Rodrik (2005).

${ }^{3}$ Albouy (2012).

${ }^{4}$ Acemoglu, Johnson and Robinson (2002).
} 
sustained extractive institutions to bolster and maintain their status. By contrast, the United States, United Kingdom and continental European countries were prosperous because, due to historical serendipities, technological advances or threats of social unrest, the elites eventually came to relinquish their political powers by adopting inclusive institutions.

Institutions ruled big time although there was China, whose path of sustained economic growth since the early-1980s could not, in any shape or form, be attributed to its political institutions. But one observation did not a rebuttal make, and institutionalists were consistent in their dismissal of China in the long run, due to its extractive and elite-friendly institutions.

To top things off, the United States and United Kingdom required no caveats until about four years ago, although the Thatcherite and Reaganite movements left nothing to the imagination since the early-1980s in their successful attempts at redesigning $U$. S. and $U$. K. institutions to the benefit of the economic and political elites. To the institutionalists, either all of this was a sideshow having little if anything to bear on stellar and exemplary political institutions that had their checks and balances. Or they were the blueprint of efficient and best-practice institutional evolution in response to rapid globalization, technological change and financial integration.

Nevertheless, the 2008 financial meltdown laid bare the extent to which American, British and to a lesser extent continental European economic, political and legal institutions have evolved in the last three decades to serve the interests of a narrow but powerful elite. The sociopolitical ramifications of this are all too well known, with a libertarian-driven, anti-government Tea Party crusade picking up steam on the one hand, and the prominence of income inequality in recent political discourse thanks to the 99-percent movement, on the other. But the role of Western political institutions in generating the 2008 financial crisis and their meager performance in its aftermath has also served to expose the soft underbelly of new institutionalism. More to the point, it exposed the weaknesses of the particular strand within the institutionalist school that has now come to dominate the academic 
narrative, with its narrower focus on formal, political and economic, extractive versus inclusive institutions.

For one, consider how, in stark contrast to the pre-crisis era, institutionalism proponents now treat the U. S. political landscape with not only alarm, but also cautious optimism. Accordingly, there is cause for concern because the financial meltdown and its aftermath have amply illustrated the tight grip of the financial oligarchs and the wealthy elite on U. S. political and legal institutions. ${ }^{5}$ But the 2008 crisis revealed absolutely nothing new in terms of the evolution of U. S. institutions, which had begun their transformation in the 1980s and kept evolving in the 1990s and 2000s in ways that became increasingly exclusive (in income and wealth and by the standards of the 1960s and 1970s). Yet, prior to 2008, the institutionalists weren't much concerned about the health of U. S. institutions. If anything, and as already mentioned, the U. S. constitutional system and its checks and balances were unabashedly touted as a blueprint for growth-enhancing but dynamic institutions. This is revisionist history put to selective use.

As the next line of defense, institutionalists are now more eager to point out that the United States has been there, done that at least once before, when the restrictive and economically-constraining political system, which produced the Gilded Age of the robber barons, was transformed into a political system with more inclusive and transparent institutions. Thus, the argument goes, U. S. institutions have enough flexibility that their checks and balances could yield self-corrections in the future. Never mind the fact that U. S. political and legal institutions were anything but inclusive until the civil rights movement of the 1960s. Institutionalism proponents ought to be highly mindful of the fact that an excessive reliance on this argument at best weakens and at worst reverses the chain of causation from institutions to economic development. After all, U. S. industrialization was well underway, if not close to complete, at the turn of the $20^{\text {th }}$ century when the aforementioned institutional revival began to take hold.

\footnotetext{
5 Johnson (2010).
} 
The second half of the first decade of the $21^{\text {st }}$ century also began to witness, in Fareed Zakaria's own terms, the rise of the rest. ${ }^{6}$ As we approach the middle of the second decade of this century, BRICs, Turkey, Vietnam are only a subsample of emerging-market economies that have sustained rapid rates of economic growth for longer than a decade. Nonetheless, by the metrics of this school of thought, half of the BRICs are in the institutional doghouse, while Brazil has nothing to write home about. Add to this Turkey, whose institutional merits—or lack thereof-about which some prominent institutionalists ought to know a thing or two, we now have more than a handful of countries that are on a path of rapid economic prosperity, in spite of their rather extractive institutions.

At some level, one could write off these new comers and late bloomers for not having proved their mettle in the long run. One could also find it acceptable to refer to the historical evolution of the U. S. institutions as an illustration of the resilience of effective institutions and the push back inherent in them thanks to a system of checks and balances. ${ }^{7}$ In doing so, however, one ought to be careful to define and categorize institutions based on function rather than form. On that basis, one should then illustrate that the evolution of institutions concurrent with and in the aftermath of economic takeoff might affect forms but not functions. The institutionalists are on relatively firm ground with respect to the first (i.e. inclusive or extractive institutions). But they are on much shakier ground regarding the second: American political institutions were anything but inclusive well into the $20^{\text {th }}$ century. Suffrage did not fully become effective until the $19^{\text {th }}$ amendment was passed in 1920, and the Civil Rights Act was signed in 1964.

Moreover, for at least two important reasons, the institutionalist school will continue to have to contend with the post-1980s American political experience and institutional evolution in the foreseeable future.

First, the U. S. political experience in the last three decades and the evolution of its formal institutions, in particular, have validated Mancur Olson's view that

\footnotetext{
${ }^{6}$ Zakaria (2008).

${ }^{7}$ That noted, there is absolutely no shortage of sources to consult on whether or not there has been institutional entropy in the United States starting in the 1980s, but for a more recent and unabashed treatment, see Ferguson (2012).
} 
constitutional democracies could very well witness systemic economic declines on the back of institutional changes that are adopted to serve special interest groups inimical to sustained growth.

Olson's key argument in The Rise and Decline of Nations (1982) is that institutional entropy and decay is part and parcel of the natural political order. As Rosser (2007) elaborates, according to Olson, “...stable democracies tend to accumulate more and more distributional coalitions whose political power will accumulate, thus gradually impeding the economic growth of the society." Focusing, in particular, "on the post-World War II performance of Germany and Japan as compared with the United Kingdom, [Olson argued] that the defeat of Germany and Japan in the war had led to the overthrow of the power of narrow special interest groups that impeded growth whereas in the [United Kingdom] such groups reached a peak of power that was responsible for the relatively weak performance of the British economy."

After riding high in the stagnant 1970s and 1980s, Olson's views had fallen out of favor in the aftermath of the fall of the Berlin wall and the decade and a half that followed. The latter, of course, being an unprecedented era of robust growth in the Western hemisphere which, based on 20/20 hindsight, was sustained, to some significant extent, first by the dot-com speculations, and then the U. S. real estate bubble. While recent developments in the United States are, at least to some extent, a culmination of the sociopolitical changes that took place in the last three decades, they are by no means proof that constitutional democracies will inevitably fall into disrepair because prosperity produces institutional decay. But they do illustrate that even best-practice constitutional democracies with their systems of checks and balances and inclusive institutions are not immune from regressions in institutional quality. Coupled with the undeniable fact that institutions are endogenous, this fragility raises the specter of Olsonian reverse causality.

Alternatively, the deep-rooted fundamentals of sustained growth could be lying elsewhere, making it all the more conspicuous that the formal political institutionalists typically give short shrift to cultural factors as well as informal and social institutions as alternative drivers of economic development. This is not to deny 
that the efficacy of political and economic institutions came to bear positively on economic development historically. ${ }^{8}$ Legal institutions govern contractual relations and the private use of force, political institutions guide the political decision-making process, and economic institutions govern interactions among economic agents. Economic and political developments thus require formal institutions that support impersonal exchange and align the incentives of political decision-makers and the public.

Nevertheless, and as I have already made clear, institutions relevant for economic development are much broader than those that the formal political institutionalists would have us believe. Indeed, the Northian institutionalist school encompasses a very important strand on the roles of beliefs, social norms and informal organizations in development. ${ }^{9}$ But, the narrow-minded focus on and the obsession with empirical identification have, to some extent, swept this literature by the wayside. Beyond that, however, there is significant evidence that leadership skills and personalities matter for how property rights and the rules of the game evolve even in strong and well-defined institutional settings. ${ }^{10}$

Social institutions, too, affect the welfare of the individual members of a society. They govern human capital formation, access to productive assets and the provision of social safety nets. Social institutions are crucial because they determine social order. Those who have nothing to live by have nothing to lose by reverting to extralegal means and disrupting the social order. Nevertheless, the role of social institutions in sustained economic growth has largely been unnoticed in the literature, although it is part and parcel of classic institutionalism.

In two papers, Greif, Iyigun and Sasson $(2011,2012)$, we refine the argument that institutional development is a precursor of sustained economic growth and

\footnotetext{
${ }^{8}$ North (1990), North and Weingast (1989), North, Wallis and Weingast (2009).

${ }^{9}$ Some of the key contributions in this strand include, but are not confined to, Greif (1993, 1994, 1998, 2006), Mokyr (2010), Kuran (1983, 1987, 1989, 2004), Alston and Ferrie (1999) and Alston and Mueller (2012).

${ }^{10}$ For example, see Toobin (2008) and Jones and Olken (2005).
} 
development in three dimensions. ${ }^{11}$ First, we focus on the importance of social institutions in the rise of the modern economy. Specifically, we consider risk-sharing institutions that influence development by raising the returns to entrepreneurial risktaking through two channels, one of which entails the entrepreneurs' own economic wellbeing in case of failure and the other which involves maintaining the social peace during times of rapid economic and social change. The importance of social institutions is evident in the transition to the modern economy. On that basis, we argue that the distinct social institutions in China and England were important in rendering England, rather than China, the first modern economy.

In Greif and Iyigun $(2012,2013)$ we empirically document the historical regularities that associate social systems of poor relief with social unrest, entrepreneurial risk-taking and discoveries: First, based on a panel covering 13 countries and the years between 950 through $1900 \mathrm{CE}$, we show that acts of social unrest and violence adversely affected discoveries internationally. Second, we document that the Old Poor Law, which was enacted in England in 1601, was particularly good at subduing social disorder, thereby encouraging risk-taking and stimulating entrepreneurial discoveries in England. In particular, based on a UK county-level panel on poor relief and social unrest from 1650 to $1818 \mathrm{CE}$, we find that variations in the amount of poor relief came to bear negatively and statistically significantly on the propensity of social unrest and disorder in England in the runup to and during the Industrial Revolution.

More relevant, however, is our argument that social and cultural factors historically impacted the design of institutions with which they subsequently coevolved. Social institutions were often chosen by the elite to avoid social upheavals. Their forms, however, were influenced by pre-existing cultural and social factors.

In sum, while recent political and financial developments in the Western hemisphere have put some heat on macroeconomists and financial economists alike for their well-documented failures, institutional economists have, for the most part,

${ }^{11}$ This line of research borrows its fundamentals from earlier work by Greif $(1993,1994,2006)$ in that informal, social institutions with deep-rooted cultural elements are at the heart of contractual relationships (or lack there of). 
remained above the fray. But the evolution of U. S. political, legal and economic institutions in the last three decades as well as the more recent economic performance of a variety of middle-income countries whose institutional qualities are at best dubious have seriously begun to challenge some of the key premises and predictions of new institutionalism which focuses on formal political institutions.

Practitioners of new institutionalism - among the ranks of whom I include myself-would be straining credibility if they say they saw the writing on the wall long ago. In fact, even as late as the summer of 2008, an overwhelming majority would have held the United States up as a model of institutional effectiveness, and prosperity with institutional root causes. If the decay and entropy in U. S. institutions were a recent phenomenon, one could discount all this as an outlier, the likes of which are hard to predict. But, as I have explained above, they weren't. Not by a long shot.

So what next, then? Let me conclude by making three observations on how the new institutionalist discourse needs to evolve in the coming years for it to maintain relevance and credibility.

First, institutionalists of all stripes need to concede that the prospect of Olsonian decay is all too real even in a most institutionally advanced economy. On that basis, they then need to more seriously entertain non-monotonicities between the levels of income and institutional quality and reverse causality running from the levels of income to institutional evolution. History is replete with civilizations that came and fell because their territorial conquests, economic growth or both eventually could not afford the social, economic and political rent seeking involved domestically.

In fact, coupled with the fact that we now have more than just China to discount as a counterexample of a rapidly-advancing economy whose institutions are sorely lacking, the prospect of a more agnostic link between formal institutions and economic development cannot be readily rejected. On that basis, those who champion formal "rules of the game" as a precursor of sustained economic growth need to come around to the view that political, legal and economic institutions are 
highly malleable even in advanced economies, while sustained economic growth is deep rooted in individual beliefs, social norms and informal cultural organizations. ${ }^{12}$

If this sounds like too radical a departure from the conventional consensus on the primacy of Northian views, then, at a minimum, those institutionalists who all along advocated the relevance of the importance of social norms, individual beliefs and informal networks need to regain their voice and reclaim their territory.

Second, and as an extension of the discussion immediately above, the new institutionalists of the "formality and political institutions rule" mold need to take a deep breath and concede that reality runs ahead of identification when it comes to the interplay between economic development and formal political institutions. Yes, development economics has been positively transformed in the last decade thanks to a single-minded focus on credible identification. But that has come at the cost of considerably narrowing the research questions involved - yawn — and focusing primarily on behavioral microeconomic issues. The classic institutionalist ideas are, by definition, big-picture arguments part of which entails emphasis on difficult to quantify and measure determinants, such as beliefs, norms and culture. Narrowing institutionalist arguments down to formal political institutions may be good identification strategy. ${ }^{13}$ However, it not only does significant disservice to the literature in general, but also is bound to crumble under the weigh of accumulating empirical evidence in the mold of Olson and the rise of the rest.

Finally, and in light of all this, institutionalists need to refrain themselves from active policy advice. Economists don't pay enough homage to the fact that context and history matter. ${ }^{14}$ There is still a lot we do not know about when it comes to why countries eventually set on a path of sustained economic growth and

\footnotetext{
12 There are some recent and important contributions in the empirical macro development literature that take these primal causal factors more seriously. See, for instance, Fernandez (2008, 2011), Nunn (2008), Nunn and Wantchekon (2011) and Nunn and Puga (2012).

13 Then, again, may be not. This literature has long been susceptible to the criticism that it had never properly identified any aspects of the formal institutional environment as the key to long-term development. Glaeser et al. (2006) make this point forcefully, arguing that Acemoglu et al. $(2001,2002)$ never properly identified the actual formal elements of political institutions. They, then demonstrate that de jure institutions do not have any strong predictable effects on growth.

${ }^{14}$ Dani Rodrik and some coauthors are among the very few in our profession who have emphasized this for over a decade now. See, for example, Hausmann and Rodrik (2003) and Hausmann, Rodrik, Velasco (2008).
} 
progress. Trumpeting western, Anglo-Saxon centric formal political institutions as the only recipe for economic prosperity might find sympathetic ears and eager media markets in the Western hemisphere, but it runs in the face of historical facts and accumulating contemporary evidence. 


\section{References}

Acemoglu, Daron, Simon Johnson, and James Robinson. (2001). "The Colonial Origins of Comparative Development," American Economic Review, 91.

Acemoglu, Daron, Simon Johnson, and James Robinson. (2002). "Reversal of Fortune: Geography and Institutions in the Making of the Modern World Income Distribution," Quarterly Journal of Economics, 117.

Acemoglu, Daron and James Robinson. (2012). Why Nations Fail, (New York, NY: Crown Books).

Albouy, David. (2012). "The Colonial Origins of Comparative Development: A Reexamination Based on Improved Settler Mortality Data," American Economic Review.

Alston, Lee J. and Joseph P. Ferrie. (1999). Southern Paternalism and the American Welfare State: Economics, Politics, and Institutions in the South, 1865-1965. (Cambridge, UK: Cambridge University Press).

Alston, Lee J. and Bernardo Mueller. (2012). "Priests, Conflicts and Property Rights: The Impacts on Tenancy and Land Use in Brazil". Working Paper, University of Colorado No. INST2012-02, May.

Easterly, William and Ross Levine. (2003). "Tropics, Germs, and Crops: the Role of Endowments in Economic Development," Journal of Monetary Economics, 50, no. 1, (January 2003): 3-39.

Ferguson, H. Charles. (2012). Predator Nation: Corporate Criminals, Political Corruption, and the Hijacking of America, (New York, NY: Crown Business).

Fernandez, Raquel. (2008). "Culture and Economics," in the New Palgrave Dictionary of Economics, 2nd edition, edited by Steven N. Durlauf and Lawrence E. Blume, Palgrave Macmillan (Basingstoke and New York).

Fernandez, Raquel. (2011). "Does Culture Matter?" in the Handbook of Social Economics, Vol 1, (New York, NY: Elsevier).

Glaeser, Edward, Rafael La Porta and Florencio Lopez-De-Silanes, Andrei Shleifer. (2006). "Do Institutions Cause Growth?" Journal of Economic Growth, 12, 185234. 
Greif, Avner. (1993). "Contract Enforceability and Economic Institutions in Early Trade: The Maghribi Traders' Coalition," American Economic Review, June, $83: 3,525-48$.

Greif, Avner. (1994). "Cultural Beliefs and the Organization of Society: Historical and Theoretical Reflection on Collectivist and Individualist Societies." Journal of Political Economy 102 (5): 91250.

Greif, Avner. (1998). "Self-Enforcing Political Systems and Economic Growth: Late Medieval Genoa," in Robert H. Bates, Avner Greif, Margaret Levi, JeanLaurent Rosenthal, and Barry R. Weingast (eds), Analytic Narratives. Princeton, NJ: Princeton University Press: 23-63.

Greif, Avner. (2006). Institutions and the Path to the Modern Economy. (Cambridge: Cambridge University Press).

Greif, Avner, Murat Iyigun and Diego Sasson. (2011). "Why England and Not China? Social Norms, Risk-Sharing Institutions and Discoveries," IZA Working Paper Series, No: 5598, March.

Greif, Avner, Murat Iyigun and Diego Sasson. (2012). "Social Organizations, Risk-Sharing Institutions and Economic Development," International Economic Association, Conference Volume, (Oxford University Press).

Greif, Avner and Murat Iyigun. (2012). "Social Institutions, Discoveries and Growth: Empirics on the Role of the Old Poor Law in the Industrial Revolution," mimeo, Stanford University.

Greif, Avner and Murat Iyigun. (2013). "Social Orgnizations, Risk-Sharing Institutions and Industrialization, American Economic Review, (P\&P), May.

Hall, Robert and Chad I. Jones. (1999). "Why do Some Countries Produce So Much More Output per Worker than Others?," Quarterly Journal of Economics, 114.

Hausmann, Ricardo and Dani Rodrik. (2003). "Economic Development as SelfDiscovery," Journal of Development Economics, vol. 72, December.

Hausmann, Ricardo, Dani Rodrik and Andres Velasco. (2008). "Growth Diagnostics," in J. Stiglitz and N. Serra, eds., The Washington Consensus Reconsidered: Towards a New Global Governance, (New York, NY: Oxford University Press). 
Iyigun, Murat and Dani Rodrik. (2005). "On the Efficacy of Reforms: Policy Tinkering, Institutional Change and Entrepreneurship," in Institutions and Growth, eds., Theo Eicher and Cecilia Garcia-Penalosa. (Cambridge: MIT Press).

Johnson, Simon. (2010). 13 Bankers: The Wall Street Takeover and the Next Financial Meltdown, (New York, NY: Pantheon).

Jones, Ben and Ben Olken. (2005). "Do Leaders Matter? National Leadership and Growth since World War II" Quarterly Journal of Economics 120 (3), pp. 835-864, August.

Kuran, Timur. (1983). "Behavioral norms in the Islamic doctrine of economics: A critique," Journal of Economic Behavior and Organization, 4, 353-379.

Kuran, Timur. (1987). "Preference falsification, policy continuity and collective conservatism," Economic Journal, 97, September, 642-665.

Kuran, Timur. (1989). "Sparks and prairie fires: A theory of unanticipated political revolution," Public Choice, 61, April, 41-74.

Kuran, Timur. (2004). Islam and Mammon: The Economic Predicaments of Islamism, (Princeton: Princeton University Press).

Mokyr, Joel. (2010). The Enlightened Economy: An Economic History of Britain 1700-1850. New Haven, CT: Yale University Press.

North, Douglass. (1990). Institutions, Institutional Change, and Economic Performance. (Cambridge, UK: Cambridge University Press).

Nunn, Nathan. (2008). "The Long Term Effects of Africa's Slave Trades," Quarterly Journal of Economics, Vol. 123, No. 1, February, pp. 139-176.

Nunn, Nathan and Leonard Wantchekon. (2011). "The Slave Trade and the Origins of Mistrust in Africa," American Economic Review, Vol. 101, No. 7, December, 3221-3252.

Nunn, Nathan and Diego Puga. (2012). "Ruggedness: The Blessing of Bad Geography in Africa," Review of Economics and Statistics, Vol. 94, No. 1, February, 20-36.

Olson, Mancur. (1982). The Rise and Decline of Nations: Economic Growth, Stagflation, and Economic Rigidities. (New Haven, CT: Yale University Press). 
Rodrik, Dani, Arvind Subramanian, and Francesco Trebbi. (2004). "Institutions Rule: The Primacy of Institutions over Geography and Integration in Economic Development," Journal of Economic Growth, 9.

Rosser, Barkley, Jr. (2007). "The Rise and Decline of Mancur Olson's View of The Rise and Decline of Nations," Southern Economic Journal, July 2007, vol. 74, no. 1, pp. 4-17.

Toobin, J. (2008). The Nine: Inside the Secret World of the Supreme Court. (New York, NY: Anchor).

Zakaria, Fareed. (2008). The Post-American World and the Rise of the Rest. (New York, NY: W. W. Norton \& Co.). 